\title{
Konservatorij Hrvaškega glasbenega zavoda v Zagrebu in konservatorij Glasbene matice v Ljubljani - primerjava
}

Nada Bezić

Hrvaški glasbeni zavod, Zagreb

Croatian Music Institute, Zagreb

Ob praznovanju jubileja konservatorija Glasbene matice je bila tema primerjave s konservatorijem Hrvaškega glasbenega zavoda (Hrvatski glazbeni zavod, v nadaljevanju: HGZ) ${ }^{1}$ iz Zagreba najbolj logična izbira. Po eni strani prav zaradi približno sočasne ustanovitve obeh konservatorijev leta $1916 \mathrm{v}$ Zagrebu in leta $1919 \mathrm{v}$ Ljubljani -, po drugi strani pa zaradi podobnosti Hrvaškega glasbenega zavoda in Glasbene matice. Ob tem je bil zagrebški Glasbeni zavod po svojem poslanstvu soroden še enemu slovenskemu glasbenemu društvu, Filharmonični družbi, ki je bila slavna pred-

$1 \quad \mathrm{~V}$ obravnavanem obdobju je imel današnji hrvaški glasbeni zavod dve različici imena: Narodni zemaljski glasbeni zavod (1861-1895) in Hrvatski zemaljski glasbeni zavod (1895-1925).

2 Tega leta je vlada potrdila odločitev HGZ, da svojo glasbeno šolo preimenuje v konservatorij (glej o tem v nadaljevanju). Zanimivo je, da Ladislav Šaban piše, da sta bili dve formalni priznanji konservatorija HGZ, prvo iz leta 1912 in drugo iz leta 1916 (Šaban, »Muzička škola Hrvatskog glazbenog zavoda u Zagrebu (1829-1920) ", v Razvoj muzičkog školstva u SR Hrvatskoj 1788-1968, katalog razstave (Zagreb: s. n., 1968), 39). Ni znano, od kod je Šaban dobil podatek o letu 1912 - sledi o tem ni niti v poročilih HGZ (Izvješće glazbene škole Hrvatskoga zem. glazbenog zavoda u Zagrebu za školsku godinu 1911.-1912. (Zagreb: [Hrvatski zemaljski glazbeni zavod], 1912); Izvješće glazbene škole Hrvatskoga zem. glazbenog zavoda u Zagrebu za školsku godinu 1912.-1913. (Zagreb: [Hrvatski zemaljski glazbeni zavod], 1913)), niti v kroniki Antuna Goglie (Hrvatski glazbeni zavod 1827.-1927. (Zagreb: [Hrvatski glazbeni zavod], 1927), zasebni natis iz časopisa Sv. Cecilija), niti v dokumentih HGZ (Vodič spisov, 4. sv. Spisi ravnateljstva 1907/8-1920/1, sestavila Marija Buljan-Janaček, Zagreb, 1976, strojepis v dokumentaciji HGZ). 
hodnica vseh glasbenih društev v habsburški monarhiji. ${ }^{3}$ Glasbeni zavod je bil ustanovljen leta 1827 kot društvo prijateljev glasbe (Societas filharmonica zagrabiensis, oziroma Musikverein).

Vsa tri omenjena glasbena društva so se temeljno ukvarjala tudi z glasbeno vzgojo. $S$ svojimi glasbenimi šolami so želela zagotoviti mlade moči za svoje ansamble in profesionalne orkestre ter izobraziti koncertno občinstvo. Šele precej let po svoji ustanovitvi so se začela ukvarjati s tem podvigom: Filharmonična družba, ustanovljena leta 1794, je glasbeno šolo ustanovila leta 1821, Glasbena matica pa točno deset let po ustanovitvi, 1882. Najhitreje je to naredil zagrebški Glasbeni zavod, saj je glasbeno šolo ustanovil dve leti po ustanovitvi, tj. leta 1829. Tako smo v letu 2019 v Zagrebu praznovali 190 let od ustanovitve glasbene šole Glasbenega zavoda, najstarejše glasbene šole na Hrvaškem, ki kontinuirano deluje vse do danes, čeprav ne več kot šola Glasbenega zavoda, ampak skozi svoji naslednici, Glasbeno akademijo (Muzička akademija Sveučilišta u Zagrebu, osnutek je nastal leta 1920) in Glasbeno šolo Vatroslava Lisinskega (Glazbena škola Vatroslava Lisinskog, ki se je od Glasbene akademije osamosvojila leta 1951). Začetki glasbene šole HGZ so bili skromni: bili so samo trije učitelji in 14 učencev, šolanje je trajalo tri leta, učili pa so petje in godalne inštrumente. Prve prostore so imeli v zagrebški gimnaziji, kjer jih je HGZ kot mlado glasbeno društvo uspelo dobiti brezplačno. Ker domačih učiteljev glasbe ni bilo, so prvi učitelji prišli v Zagreb iz drugih krajev monarhije. Učenci so bili samo fantje. ${ }^{4}$

Glasbena šola glasbenega zavoda je postala ključna točka na zemljevidu glasbene kulture in izobraževanja v tem delu Evrope. V Zagreb so prihajali celo učenci iz Bolgarije -avtor prve bolgarske simfonije Nikola Atanasov (1886-1969) se je izobraževal v šoli zavoda in je svojo simfonijo premierno dirigiral na šolski produkciji leta 1912.

Med učenci šole so bili redno tudi Slovenci, pomembnejši pa so bili učitelji slovenskega rodu, še posebej dirigent, organist in skladatelj Anton

3 O tej paraleli je bilo govora na enem od prejšnjih simpozijev Slovenskih glasbenih dnevov, vzp.: Nada Bezić, »Hrvaški glasbeni zavod v Zagrebu in Filharmonična družba v Ljubljani - primerjava in kontakti«, v Ob 30o. obletnici ustanovitve Academiae philharmonicorum labacensium in 10o. obletnici rojstva skladatelja Blaža Arni$\check{c} a$, ur. Primož Kuret (Ljubljana: Festival Ljubljana, 2001), 75-82.

$4 \quad \mathrm{O}$ začetku glasbene šole je pisal Ladislav Šaban v svoji knjigi 150 godina Hrvatskog glazbenog zavoda (Zagreb: Hrvatski glazbeni zavod, 1982), 60 in 62, in v zasebnem besedilu »Muzička škola Hrvatskog glazbenog zavoda u Zagrebu (1829-1920)《. 
Stöckl (1851-1902). ${ }^{6} \mathrm{Na}$ glasbeni šoli HGZ v Zagrebu je od leta 1883 do smrti poučeval petje, klavir, harmonijo, kontrapunkt in kompozicijo, bil je tudi dirigent šolskih koncertov in še posebej pomemben kot dirigent prve izvedbe Beethovnove Devete simfonije v Zagrebu leta 1900. ${ }^{7}$

Glasbena šola Glasbenega zavoda je bila v 19. stoletju glavna in delno tudi edina glasbena šola $\mathrm{v}$ Zagrebu in je imela ambicije, da bi se razvila $\mathrm{v}$ višjo glasbeno šolo, torej konservatorij. Na ozemlju današnje Hrvaške tedaj ni imela konkurence, čeprav so v začetku 20. stoletja delovale glasbene šole v mnogih mestih Hrvaške. ${ }^{8}$

$\mathrm{V}$ zgodovini glasbene šole HGZ je imel pomembno vlogo skladatelj Ivan Zajc (1832-1914), direktor šole od leta 1870 do 1908 in ključna osebnost glasbenega življenja v Zagrebu v tem času. ${ }^{\prime}$ Najpomembnejša oseba v tem kontekstu pa je bil Vjekoslav Klaić (1849-1928), kot dober primer osebnosti, ki je imela sposobnosti za reformo glasbene šole. Bil je sin pedagoga, na začetku kariere je bil učitelj na gimnaziji, pozneje pa je postal univerzitetni profesor in eden najvidnejših hrvaških zgodovinarjev. Z glasbo se je ukvarjal kot zgodovinar, publicist in kritik, organizator zagrebškega glasbenega življenja ter kot skladatelj, melograf in dirigent. ${ }^{10}$ Od leta 1890 do 1928 je bil

6 Omeniti je treba, da relevantni hrvaški in slovenski leksikografski viri ne navajajo istega leta rojstva. Stanko Premrl je v Stöcklovi biografiji zapisal letnico 1850 (Stanko Premrl, »Stöckl, Anton«, Slovenska biografija (Ljubljana: Slovenska akademija znanosti in umetnosti, Znanstvenoraziskovalni center SAZU, 2013), https:// www.slovenska-biografija.si/oseba/sbi614474/), v nepodpisanih biografijah publikacij zagrebškega Leksikografskega zavoda Miroslav Krleža pa je navedena letnica 1851 (Anon., »Stöckl, Anton«, v Leksikon jugoslavenske muzike, 2. zv., ur. Krešimir Kovačević (Zagreb: Jugoslavenski leksikografski zavod Miroslav Krleža, 1984), 378; Anon., "Stöckl, Anton«, v Hrvatska enciklopedija, http://www.enciklopedija.hr/Natuknica.aspx? ID=58191).

7 Anon., »Na kraju Beethovenove godine«, $\mathrm{HaGeZe} 4$, št. 3 (2002): 3. O Stöcklu je obsežno in zanimivo pisal Antun Goglia leta 1927 (Hrvatski glazbeni zavod 1827. - 1927. (Zagreb: [Hrvatski glazbeni zavod], 1927), 57, opomba 45).

8 V Splitu, Osijeku, Zadru, Varaždinu, Bjelovarju, Slavonskem Brodu, Sisku, Reki, Karlovcu in dr. Vzp.: Anon., »Školstvo. Hrvatska«, v Leksikon jugoslavenske muzike, 2. zv., ur. Krešimir Kovačević (Zagreb: Jugoslavenski leksikografski zavod Miroslav Krleža, 1984), 415.

9 Najobširneje je o Zajcu in Hrvaškem glasbenem zavodu pisal Zdravko Blažeković v delu Djelatnost Ivana Zajca u okvirima Hrvatskog zemaljskog glazbenog zavoda v zborniku Zbornik radova sa znanstvenog skupa održanog u povodu 15o. obljetnice rođenja Ivana Zajca (1832-1914): Zagreb, 10.-11. prosinca 1982., ur. Lovro Županović (Zagreb: Jugoslavenska akademija znanosti i umjetnosti, Razred za muzičku umjetnost; Muzikološki zavod Muzičke akademije u Zagrebu, 1982), 55-78.

10 Več o glasbenem delovanju Klaića glej v: Sanja Majer-Bobetko, »Vjekoslav Klaić«, Hrvatski biografski leksikon, http://hbl.lzmk.hr/clanak.aspx?id=214. 
podpredsednik Zavoda in ga tri desetletja praktično vodil, saj je bil tedanji društveni predsednik Julije Drohobeczky (predsednik HGZ od 1893 do 1919) škof v Križevcih, mestu vzhodno od Zagreba. Klaić je posebej skrbel za glasbeno šolo in vpeljal številne reforme in izboljšave. Na njegovo pobudo so bili izdelani osnovni predpisi glasbene šole, ${ }^{\text {II }}$ pouk je bil razširjen na večino orkestralnih instrumentov, na šolo pa so prišli poučevat učitelji, ki so se izobraževali na priznanih evropskih konservatorijih (npr. Leonija Brückl (1857-1927) za petje, Anka Barbot-Krežma (1859-1914) za klavir in Čeh Roman Vitězslav Moser (1864-1939) za violino).

Klaićevo delovanje je podobno delovanju Frana Gerbiča, pevca, skladatelja in direktorja glasbene šole Matice v Ljubljani (1840-1917). Bila sta predstavnika iste generacije, podobna so bila tudi njuna velika prizadevanja, kako sta vodila vsak svojo glasbeno šolo. Gerbič je bil dobro seznanjen $\mathrm{z}$ zagrebško glasbeno sceno, saj je v sedemdesetih letih 19. stoletja nastopal kot tenor $\mathrm{v}$ zagrebški operi, kjer ga je $\mathrm{v}$ občinstvu zagotovo poslušal tudi mladi Klaić. ${ }^{12}$ Oba sta tri desetletja (Klaić celo 38 let!) svojega zrelega ustvarjalnega življenja namenila glasbeni šoli v Ljubljani oziroma Zagre$\mathrm{bu}$, pri čemer sta veliko prispevala $\mathrm{k}$ napredku šole na poti $\mathrm{h}$ konservatoriju. Gerbič ustanovitve konservatorija žal ni dočakal. Narodna in univerzitetna knjižnica v Ljubljani hrani njuno korespondenco iz obdobja pred ustanovitvijo konservatorija in verjetno bo nadaljnje raziskovanje tega gradiva odkrilo dragocene nove podatke. ${ }^{13}$ Obstaja še druga zanimiva vzporednica: Gerbič je imel uspešno kariero v tujini, vendar se je vrnil v Ljubljano, da bi prevzel svoje dolžnosti na glasbeni šoli Matice. Enako je Ivan Zajc pustil svojo kariero operetnega skladatelja na Dunaju in prišel v Zagreb, na šolo Glasbenega zavoda.

Glasbena matica in HGZ sta imela kot glasbeni društvi podoben krog delovanja, zato ne preseneča, da sta vzdrževala stik. Zavod je leta 1892 postal podporni član Glasbene matice in se pozneje odzval tudi na zbiranje pomoči, in sicer leta 1895 po potresu v Ljubljani. ${ }^{14} \mathrm{Ob}$ primerjavi obeh konser-

11 Klaić je bil avtor Disciplinskega reda za učence in Naukovne osnove za posamezne predmete, glej: Šaban, 150 godina Hrvatskog glazbenog zavoda, 102-103. Vzp.: Nada Bezić, »Fran Gerbič v Zagrebu«, v Gerbičev zbornik, ur. Edo Škulj (Ljubljana: Družina, 2000), 17-30.

13 Glej: Nataša Cigoj Krstulović, Zgodovina, spomin, dedǐ̌čina: ljubljanska Glasbena matica do konca druge svetovne vojne (Ljubljana: Založba ZRC, ZRC SAZU, 2015), 67, opomba 101; 101.

14 Šaban, 150 godina Hrvatskog glazbenog zavoda, 107. 
vatorijev se zastavlja vprašanje, kaj je potrebno, da glasbena šola postane konservatorij.

Prvi pogoj je dobro organizirana večstopenjska šola. V obeh mestih sta imeli glasbeni šoli nižjo in višjo stopnjo ter pripravljalne razrede. V Zagrebu je bilo tako že od prvih let Klaićeve uprave, ${ }^{\text {I5 }} \mathrm{v}$ Ljubljani pa so organizirali tudi pripravljalne tečaje za zborovsko petje odraslih pevcev. ${ }^{16} \mathrm{Ob}$ tem so bili za osnutek konservatorija potrebni vsi temeljni šolski dokumenti, pravila in učni načrti za vse predmete. Ti dokumenti so bili v obeh mestih zagotovljeni v osemdesetih in devetdesetih letih 19. stoletja. Že v prvem pomembnem dokumentu iz Klaićevega obdobja, tj. Nacrt temeljnoga statuta ... iz leta 1891, je v prvem členu zapisano, da je namen Zavoda skrbeti za glasbeno šolo do osnovanja pravega konservatorija. ${ }^{17}$

Tabela r: Pravila in dokumenti - primerjava $^{{ }^{18}}$

\begin{tabular}{|c|c|c|c|}
\hline HGZ & Glasbena matica & HGZ & Glasbena matica \\
\hline $\begin{array}{l}\text { Nacrt temeljnoga statuta za na- } \\
\text { rodni zemaljski glasbeni zavod u } \\
\text { Zagrebu }\end{array}$ & Šolski red & 1891 & \\
\hline Osnova statuta za učitelje zavoda & $\begin{array}{l}\text { Uredba za učiteljsko osebje } \\
\text { Glasbene matice }\end{array}$ & 1890 & 1896 \\
\hline Disciplinarni red za učenike & $\begin{array}{l}\text { Vodila Glasbene matice v } \\
\text { Ljubljani za gojence glasbe- } \\
\text { ne šole }\end{array}$ & 1893 & 1882 \\
\hline Pravilnik o ispitima zrelosti & & 1894 & \\
\hline $\begin{array}{l}\text { Nacrt za opernu i dramatsku ško- } \\
\text { lu }\end{array}$ & & 1895 & \\
\hline Naučna osnova za predmete & $\begin{array}{l}\text { Učni načrt Glasbene matice v } \\
\text { Ljubljani }\end{array}$ & $1895 / 96$ & 1887 \\
\hline $\begin{array}{l}\text { Pravilnik mirovne zaklade za mi- } \\
\text { rovine profesora }\end{array}$ & & 1897 & \\
\hline
\end{tabular}

15 »Pripravni tečaj«, od šolskega leta 1892/1893, glej Izvješće Narodnoga zemaljskoga Glasbenoga zavoda u Zagrebu koncem školske godine 1892/3. (Zagreb: [Narodni zemaljski glasbeni zavod], 1893).

16 Cigoj Krstulović, Zgodovina, spomin, dediščina, 65.

17 Izvješće Narodnoga zemaljskoga glasbenoga zavoda u Zagrebu koncem srpnja godine 1891. (Zagreb: [Narodni zemaljski glasbeni zavod], 1891), 7.

18 Podatki za HGZ prevzeti iz: Šaban, 150 godina Hrvatskog glazbenog zavoda, 102, in Izvješće Narodnoga zemaljskoga glasbenoga zavoda u Zagrebu koncem srpnja godine 1891., 7-12. Za Glasbeno matico so podatki prevzeti iz Cigoj Krstulović, Zgodovina, spomin, dediščina, 312 . 
Kot piše Nataša Cigoj Krstulović, se je šola Glasbene matice pripravljala na konservatorij "z zviševanjem zahtevnostne ravni pouka ter postopnim uvajanjem pouka vseh inštrumentov in teoretičnih predmetov«. ${ }^{19}$

Ko sta obe šoli postali konservatorij, sta imeli pouk vseh godalnih inštrumentov (razen viole), petja, zbora, orkestra, osnovnih pihal, teoretičnih predmetov in kompozicije, italijanskega jezika in zgodovine glasbe. ${ }^{20}$

Ključni dejavnik za ustanovitev vsakega konservatorija so pedagogi z visokošolskimi kvalifikacijami. Ker v obeh mestih ni bilo dovolj primerno izobraženih domačih pedagogov, sta obe glasbeni šoli objavili razpis za službo za učitelje tudi zunaj svoje dežele. Pri tem je Glasbena matica dobila pomoč tudi od Leopolda Alexandra Zellnerja (1823-1894), tajnika dunajskega Gesellschaft der Musikfreunde, rojenega v Zagrebu. ${ }^{21}$ Eden od pogojev za zaposlitev je bilo seveda znanje slovenskega oziroma hrvaškega jezika kot učnega jezika ali vsaj pripravljenost, da bi se ga kandidati za učitelje hitro naučili. ${ }^{22} \mathrm{~V}$ učiteljski zbor glasbenih šol so sprejeli tudi domače glasbenike, ki so študirali v tujini, kot je bil na primer Matej Hubad.

Omeniti je treba še učbenike in priročnike, saj sta si obe šoli prizadevali za spodbujanje učiteljev $\mathrm{k}$ pisanju priročnikov $\mathrm{v}$ maternem jeziku. $\mathrm{V}$ Zagrebu so bile to publikacije iz devetdesetih let 19. stoletja: učbenik za violino $^{23}$ in Kratak opći nauk o glasbi za učenike glazbene škole Hrv. zemaljskoga glazbenoga zavoda Antona Stöckla ${ }^{24}$ ter pesmarica. ${ }^{25}$ Glasbena matica

19 Cigoj Krstulović, Zgodovina, spomin, dediščina, 67.

20 Pihala v Zagrebu: flavta, oboa, rog, trobenta, pozavna. Glej Izvještaj Konzervatorija Hrvatskoga zemaljskoga Glazbenoga zavoda u Zagrebu za školsku godinu 1916-1917. (Zagreb: [Hrvatski zemaljski glazbeni zavod], 1917), 4-9.

21 Cigoj Krstulović, Zgodovina, spomin, dediščina, 61 in 66. O Zellnerju glej: Anon., "Zellner, Leopold Alexander«, v Leksikon jugoslavenske muzike, 2. zv., ur. Krešimir Kovačević (Zagreb: Jugoslavenski leksikografski zavod Miroslav Krleža, 1984), 555.

22 Cigoj Krstulović, Zgodovina, spomin, dediščina, 60; "znanje hrvatskog ili bar kojeg drugog slavenskog jezika", Izvješće Narodnoga zemaljskoga glasbenoga zavoda u Zagrebu koncem srpnja godine 1891., 55.

23 Vitězslav Roman Moser, Tehničke vježbe za gusle, za porabu učenicima i učenicama Narodnoga zemaljskoga glasbenoga zavoda, 2 zvezka (Zagreb: Tiskara i litografija C. Albrechta, 1894).

24 Anton Stöckl, Kratak opći nauk o glasbi za učenike glazbene škole Hrv. zemaljskoga glazbenoga zavoda (Zagreb: Hrvatski zemaljski glazbeni zavod, 1899).

Anon., Hrvatska pjesmarica, za porabu učenicima i učenicama Narodnoga zemaljskoga glasbenoga zavoda, dva zvezka (Zagreb: s. n., 1893 in 1894). Ladislav Šaban piše, da sta zbirko pripravila Vjekoslav Klaić in tajnik šole Milutin Farkaš (Šaban, 150 godina Hrvatskog glazbenog zavoda, 112). 
je imela nekaj več učbenikov - od leta 1885 do leta 1913 so izdali učbenike za petje, ${ }^{26} \mathrm{klavir}^{27}$ teorijo ${ }^{28}$ in zvezek skladb za violino in klavir. ${ }^{29}$

Tudi prostorske razmere so bile podobne: Glasbeni zavod je imel že od leta 1876 lastno stavbo, ki so jo prav v Klaićevem obdobju (leta 1895) še razširili, Glasbena matica pa je imela stavbo od leta 1896. Ladislav Šaban je kot merilo za resnično delovanje glasbene šole kot konservatorija navedel tudi štipendije, ki bi na zagrebški konservatorij privabile nadarjene učence iz drugih krajev Hrvaške. ${ }^{30}$

Končni pogoj za ustanovitev konservatorija so prošnje vladi in njena finančna pomoč, saj se $\mathrm{v}$ obeh mestih ni bilo mogoče zanašati na lastna sredstva in moči, poleg tega okolje ni bilo dovolj zrelo za delovanje zasebnega konservatorija. Upoštevati je treba tudi zgodovinske razmere, zlasti vojne. Prva vloga za ustanovitev zagrebškega konservatorija je bila vladi poslana že leta 1848 , vendar je to pobudo ustavila vojna $z$ Madžarsko. ${ }^{31}$ Zanimivo je, da je bila tudi ustanovitev konservatorijev v obeh mestih povezana $z$ vojno: v Zagrebu so konservatorij ustanovili med prvo svetovno vojno, v Ljubljani pa takoj po njej.

$\mathrm{V}$ pripravah na konservatorij sta se glasbeni šoli zgledovali po podobnih konservatorijih v monarhiji, predvsem po Dunaju ter po Pragi in Würzburgu, ${ }^{32}$ ljubljanski pa tudi po Zagrebu. ${ }^{33}$ Tem bolj je čudno, da je bila v prvem imenu ljubljanskega konservatorija beseda prvi (Prvi jugoslovanski konservatorij), ker, kot je zapisal Cvetko Budkovič, "glede prvenstva

26 Anton Razinger, Začetne pevske vaje (Ljubljana: Glasbena matica, 1885), http://www. dlib.si/?URN=URN:NBN:SI:DOC-5VKPAW30; Anon., 7 pesmic za otroke (Ljubljana: Glasbena matica, 1904), http://www.dlib.si/?URN=URN:NBN:SI:DOC-U5YHOVHX; [?] Zöllner, Štirideset vaj v petju (s. l. n., 1908).

27 Anton Foerster, Teoretično-praktična klavirska šola, 4 zvezki (Ljubljana: Glasbena matica, 1886-1889), http://www.dlib.si/?URN=URN:NBN:SI:DOC-XVMSNSGZ.

28 Matej Hubad, Splošna, elementarna glasbena teorija ali začetni nauk o glasbi (Ljubljana: Glasbena matica, 1902), http://www.dlib.si/?URN=URN:NBN:SI:DOCEMBUVBXN.

29 Žiga (Sigismund) Polášek, Josip (Josef) Vedral, Slovenski mladini: Album 25 slovenskih pesmi za gosli s spremljevanjem klavirja (Ljubljana: Glasbena matica, 1913), http://www.dlib.si/?URN=URN:NBN:SI:DOC-AZVPBWHE. Podatki o publikacijah Glasbene matice iz: Cigoj Krstulović, Zgodovina, spomin, dediščina, 50.

30 Šaban, »Muzička škola Hrvatskog glazbenog zavoda u Zagrebu (1829-1920)«, 39.

31 Šaban, 150 godina Hrvatskog glazbenog zavoda, 73.

32 Prvi načrt za konservatorij v Zagrebu iz leta 1849 je narejen po zgledu konservatorija v Pragi (ibid., 73-74). Po drugi strani pa je Klaić menil, da bi zagrebškim razmeram najbolj ustrezala organizacija, kot je konservatorij v Würzburgu (ibid., 10o). 
konservatorija za glasbo in igralsko umetnost v jugoslovanskem prostoru seveda ni[so] imel[i] prav«. ${ }^{34}$

Podatek, da je Hrvaški glasbeni zavod svojo šolo razglasil za konservatorij, je še posebej zanimiv z dveh vidikov. Najprej zato, ker je bil to samostojni akt uprave Zavoda, ne pa odločitev pristojnih organov, kar se nam danes lahko zdi nemogoče v birokratsko tako urejeni državi, kot je bila Avstro-Ogrska. Treba je upoštevati, da je birokracija popuščala svojo strogost med vojno, ko je monarhija izginjala. Prav oktobra 1916, ko je vlada izdala potrdilo o ustanovitvi konservatorija, je Franc Jožef zbolel in kmalu umrl. Pri drugem vidiku gre za razumevanje tega, kaj se je dejansko zgodilo v glasbeni šoli, torej kateri so bili argumenti, da je uprava zavoda šolo preimenovala $\mathrm{v}$ konservatorij. $\mathrm{V}$ dveh temeljnih zgodovinskih delih glasbenega zavoda, v kroniki Antuna Goglie iz leta $1927^{35}$ in knjigi Ladislava Šabana 150 let Hrvaškega glasbenega zavoda iz leta 1982, so razvidni nekateri sledovi preoblikovanja organizacije, vendar le preimenovanja - Šaban je celo zapisal, da je uprava od oblasti »izsilila" potrditev razglasitve konservatorja ${ }^{36}$ in ga imenovala Konzervatorij Hrvatskog zemaljskog glazbenog zavoda, krajše: Hrvatski konzervatorij. Kot so napisali v izvestju leta 1917:

Ravnateljstvo je hotelo s tem sklepom ovreči napačno razumevanje neobveščenih krogov, ki mislijo, da ta glasbena šola zavoda po svoji zgradbi in učnem načrtu ni popolnoma enakovredna drugim konservatorijem, ampak le nekakšna priprava za takšne višje šole. ${ }^{37}$

Dobrih deset let, preden je izšla Šabanova knjiga o zavodu, je v svojem besedilu o glasbeni šoli HGZ zapisal tezo, da je bila zavodska šola de facto konservatorij že 25 let pred uradnim imenovanjem, torej leta 1891, ko je zaživela Klaićeva reforma glasbene šole..$^{38}$ Dejansko bi se lahko letnica usta-

34 Cvetko Budkovič, Razvoj glasbenega šolstva na Slovenskem II, od nastanka konservatorija do Akademije za glasbo 1919-1946 (Ljubljana: Znanstveni inštitut Filozofske fakultete, 1995), 18.

35 Goglia, Hrvatski glazbeni zavod 1827-1927.

36 Ravnateljstvo je »iznudilo od vlade njegovu potvrdu«, Šaban, 150 godina Hrvatskog glazbenog zavoda, 102.

37 »Ravnateljstvo je tim zaključkom htjelo stati na put posve krivomu mnijenju neupućenih krugova, koji misle, da ova zavodska glazbena škola nije po svojemu ustroju, ni po naučnoj osnovi posve ravna ostalim konzervatorijima, već da je tek neka priprava za ovakove više škole. "Izvještaj Konzervatorija Hrvatskoga zemaljskoga Glazbenoga zavoda u Zagrebu za školsku godinu 1916-1917., 30.

38 Šaban, »Muzička škola Hrvatskog glazbenog zavoda u Zagrebu (1829-1920)«, 37-38, kjer je zapisal: »Glazbeni zavod već od 1891. zaista djeluje kao konzervatorij, premda 
novitve konservatorija premaknila v devetdeseta leta 19. stoletja, ampak ne v leto 1891, ko se je Klaićeva reforma šele začela, temveč v leto 1896, ko je imela glasbena šola v primerjavi z letom $1891 \mathrm{z}$ novo stavbo HGZ (zgrajeno ob stari stavbi iz leta 1876) boljše prostorske razmere, učbenike, skoraj 50 ur pouka tedensko več, štipendiste in temeljne dokumente. Ob tem je imela glasbena šola zavoda v šolskih letih 1895/96 in 1916 enake temeljne pogoje za ustanovitev konservatorija: pripravljalno, nižjo in višjo raven, šolske statute in pravilnike, kvalificirane pedagoge, izdani so bili učbeniki in priročniki iz teorije, violine in zborovskega petja in končno najpomembnejše: ustanovljena je bila šola s tradicijo in ugledom. Edina poglavitna razlika je, da so imeli leta 1916 seveda več učencev in učiteljev kot dvajset let prej (120 učencev več in kakšnih deset učiteljev več). Predmeti so bili na splošno enaki, leta 1916 so bili v primerjavi z letom $1896 \mathrm{v}$ predmetnik dodani še kompozicija, deklamacija, mimika in timpani. Celo funkcije vodilnih oseb šole so ostale iste: ravnatelj, tajnik šole in nadzornica učenk (torej ne nadzornica vseh učencev, ampak samo učenk!).

\section{Tabela 2. Primerjava glasbene šole in konservatorija HGZ}

\begin{tabular}{|c|cc|}
\hline & \multicolumn{1}{|c}{$1895 / 1896^{39}$} & $1916 / 1917^{40}$ \\
\hline $\begin{array}{c}\text { Število učencev } \\
\text { Število učiteljev }\end{array}$ & 262 & 383 \\
\hline $\begin{array}{c}\text { Število pomožnih } \\
\text { učiteljev }\end{array}$ & 10 & 7 \\
\hline Predmeti & 5 & $\begin{array}{l}\text { Petje, operni ensemble, klavir, go- } \\
\text { dalna glasbila, lesena pihala, rog, } \\
\text { trobenta, pozavna, harfa, orgle, or- } \\
\text { kester, komorna glasba, teorija glas- } \\
\text { be, harmonija, kontrapunkt in fuga, } \\
\text { oblikoslovje, zgodovina glasbe, hr- } \\
\text { vaški jezik in književnost, italijan- } \\
\text { ski jezik in konverzacija, instru- } \\
\text { mentacija in igranje partitur }\end{array}$ \\
\hline
\end{tabular}

Formalno lahko rečemo, da je bil konservatorij Hrvaškega glasbenega zavoda de facto ustanovljen v šolskem letu 1895/1896. Vendar je za šolo bolj kot njena organizacija pomembna njena vsebina - kakovost pouka. Vpraša-

to još pravno nije.« Zanimivo je, da v svoji knjigi te teze ni tako poudaril (Šaban, 150 godina Hrvatskog glazbenog zavoda, 102).

39 Izvješce Narodnoga zemaljskoga Glasbenoga zavoda u Zagrebu koncem školske godine 1895/6. (Zagreb: [Narodni zemaljski glasbeni zavod], 1896).

40 Izvještaj Konzervatorija Hrvatskoga zemaljskoga Glazbenoga zavoda u Zagrebu za školsku godinu 1916-1917. 
ti se moramo, kdaj je kakovost pouka dosegla konservatoriju primerno raven. Tega trenutka ni mogoče točno določiti, vendar se je to najverjetneje zgodilo do leta 1916. Morda je bil ta trenutek leta 1903, ko je v Zagreb prišel Václav Huml (1883-1953), pozneje slavni violinistični pedagog in začetnik t. i. zagrebške violinistične šole. Istega leta je začela poučevati učiteljica petja Leonija Brückl, ki je vzgojila pevce, kot je v Ljubljani dobro znana sopranistka Zlata Gjungjenac (1898-1982). Torej čeprav bi morali šteti, da je konservatorij morebiti nastal leta 1896 , pravega začetka pouka na ravni konservatorija ni mogoče z gotovostjo datirati.

Sklepna primerjava konservatorijev v Zagrebu in Ljubljani kaže, da sta bila oba le kratek čas $\mathrm{v}$ rokah glasbenih društev, preden ju je prevzela država: zagrebški samo štiri leta, od leta 1916 do leta 1920, ljubljanski pa sedem let, do leta 1926. Primerjava nekaterih statističnih podatkov je zelo zanimiva: ko so nastajali konservatoriji (natančneje: leta 1910), je imel Zagreb dvakrat več prebivalcev kot Ljubljana. ${ }^{41}$ Kljub temu je imel novi konservatorij leta $1919 \mathrm{v}$ tedaj mali Ljubljani dvakrat več učencev kot konservatorij HGZ. $^{42}$

$\mathrm{Na}$ koncu se pojavi še eno vprašanje: če glasbeno društvo, kot je na primer Glasbeni zavod ali ljubljanska Matica, tako vztrajno vzdržuje svojo glasbeno šolo kot eno od prednostnih nalog, kakšno perspektivo za to šolo ima v svojih načrtih? Na prvi pogled bi lahko domnevali, da bosta društvi vztrajali pri tem, da obdržita konservatorij pod svojim okriljem, vendar ni bilo tako. Obe društvi sta imeli v načrtu, da upravljanje svoje šole predata državi tedaj, ko se bosta razvili v konservatorij. ${ }^{43} \mathrm{~V}$ Zagrebu je bilo tako že leta 1851, ko je skladatelj Vatroslav Lisinski (1819-1854), kot šolani pravnik in član ravnateljstva, $v$ drugi člen statuta glasbenega društva zapisal, da je eden od ciljev zbiranje glavnice za konservatorij. ${ }^{44}$ Od tedaj je Zavod vlado

41 Anon., »Zagreb«, v Hrvatska enciklopedija, http://www.enciklopedija.hr/natuknica. aspx?id $=66685$.

V šolskem letu 1919/1920 je imel konservatorij HGZ 508 učencev (Izvještaj Konzervatorija Hrvatskoga zemaljskoga glazbenoga zavoda u Zagrebu za školsku godinu 1919.-1920. (Zagreb: [Hrvatski zemaljski glazbeni zavod], 1920), 21), ljubljanski pa več kot 1.00o učencev (Cigoj Krstulović, Zgodovina, spomin, dediččina, 167).

Kot je znano, so imeli podobno usodo tudi drugi konservatoriji v monarhiji, na čelu z dunajskim konservatorijem, ki je leta 1909 postal državna institucija. Glej tudi: Heinrich Kralik, Das Buch der Musikfreunde (Zürich, Leipzig, Wien: Gesellschaft der Musikfreunde, 1951), 171-176.

»skupljanjem glavnice za utemeljenje narodnog konservatoriuma«, Pravila Družtva prijateljah muzike u Zagrebu (Zagreb: [Družtvo prijateljah muzike u Zagrebu], 1852), 1 [3]. 
večkrat prosil, naj financira konservatorij, ampak zaman. Zanimivo je, da je vztrajanje pri konservatoriju privedlo do tega, da je ob njegovi ustanovitvi na nek način izrinil pomen Glasbenega zavoda. Kako drugače pojasniti, da imajo programi koncertov v dvorani Zavoda po letu 1916 kot lokacijo napisano Hrvatski konzervatorij, ne pa Glazbeni zavod?

Primerjava ustanoviteljev konservatorija v Ljubljani in Zagrebu danes kaže različno usodo: medtem ko je stavba Glasbene matice na Vegovi ulici vsak dan polna mladih glasbenikov, je stavba glasbenega zavoda po tem, ko se je leta 2015 iz nje izselila Glasbena akademija, čez dan veliko bolj tiha, ker še ni končana reorganizacija celotne stavbe. Na vsak način je v tem kontekstu pomembnejše, da ima Glasbena akademija, naslednica konservatorija HGZ, odlične razmere za delo in vzgojo novih glasbenih umetnikov.

\section{Bibliografija}

Anon. 7 pesmic za otroke. Ljubljana: Glasbena matica, 1904. http://www.dlib. si/?URN=URN:NBN:SI:DOC-U5YHOVHX.

Anon. Hrvatska pjesmarica, za porabu učenicima i učenicama Narodnoga zemaljskoga glasbenoga zavoda. Zagreb: s. n., 1893 in 1894.

Anon. »Na kraju Beethovenove godine«. HaGeZe IV, št. 3 (2002): 3.

Anon. »Stöckl, Anton«. V Hrvatska enciklopedija, http://www.enciklopedija.hr/ Natuknica.aspx?ID=58191.

Anon. „Stöckl, Anton«. V Leksikon jugoslavenske muzike, 2. zv., ur. Krešimir Kovačević, 378. Zagreb: Jugoslavenski leksikografski zavod Miroslav Krleža, 1984.

Anon. „Školstvo. Hrvatska«.V Leksikon jugoslavenske muzike, 2. zv., ur. Krešimir Kovačević, 415. Zagreb: Jugoslavenski leksikografski zavod Miroslav Krleža, 1984 .

Anon. »Zagreb«. V Hrvatska enciklopedija, http://www.enciklopedija.hr/natuknica.aspx?id=66685.

Anon. »Zellner, Leopold Alexander«. V Leksikon jugoslavenske muzike, 2. zv., ur. Krešimir Kovačević, 555. Zagreb: Jugoslavenski leksikografski zavod Miroslav Krleža, 1984.

Bezić, Nada. »Fran Gerbič v Zagrebu«. V Gerbičev zbornik, ur. Edo Škulj, 17-3o. Ljubljana: Družina, 2000.

Bezić, Nada. »Hrvaški glasbeni zavod v Zagrebu in Filharmonična družba v Ljubljani - primerjava in kontakti«. V Ob 30o. obletnici ustanovitve Academiae philharmonicorum labacensium in 10o. obletnici rojstva skladatelja Blaža Arniča, ur. Primož Kuret, 75-82. Ljubljana: Festival Ljubljana, 2001. 
Blažeković, Zdravko. »Djelatnost Ivana Zajca u okvirima Hrvatskog zemaljskog glazbenog zavoda«. V Zbornik radova sa znanstvenog skupa održanog u povodu 150. obljetnice rođenja Ivana Zajca (1832-1914): Zagreb, 10-11. prosinca 1982., ur. Lovro Županović, 55-78. Zagreb: Jugoslavenska akademija znanosti i umjetnosti, Razred za muzičku umjetnost; Muzikološki zavod Muzičke akademije u Zagrebu, 1982.

Budkovič, Cvetko. Razvoj glasbenega šolstva na Slovenskem II, od nastanka konservatorija do Akademije za glasbo, 1919-1946. Ljubljana: Znanstveni inštitut Filozofske fakultete, 1995.

Cigoj Krstulović, Nataša. Zgodovina, spomin, dediščina: ljubljanska Glasbena matica do konca druge svetovne vojne. Ljubljana: Založba ZRC, ZRC SAZU, 2015.

Dokumenti HGZ. Vodič spisov, 4. sv. Spisi ravnateljstva 1907/8-1920/1, sestavila Marija Buljan-Janaček, Zagreb, 1976, strojepis v dokumentaciji HGZ-a

Foerster,Anton.Teoretično-praktičnaklavirskašola, 4zvezki.Ljubljana:Glasbenamatica, 1886-1889. http://www.dlib.si/?URN=URN:NBN:SI:DOC-XVMSNSGZ.

Goglia, Antun. Hrvatski glazbeni zavod 1827-1927. Zagreb: Hrvatski glazbeni zavod, 1927 (zasebni natis iz časopisa Sv. Cecilija).

Hubad, Matej. Splošna, elementarna glasbena teorija ali začetni nauk o glasbi. Ljubljana: Glasbena matica, 1902.

Izvješće Narodnoga zemaljskoga glasbenoga zavoda u Zagrebu koncem srpnja godine 1891., Zagreb: Narodni zemaljski glasbeni zavod, 1891.

Izvješće Narodnoga zemaljskoga Glasbenoga zavoda u Zagrebu koncem školske godine 1892/3. Zagreb: Narodni zemaljski glasbeni zavod, 1893.

Izvješće Narodnoga zemaljskoga Glasbenoga zavoda u Zagrebu koncem školske godine 1895/6. Zagreb: Narodni zemaljski glasbeni zavod, 1896.

Izvješće glazbene škole Hrvatskoga zem. glazbenog zavoda u Zagrebu za školsku godinu 1911.-1912. Zagreb: Hrvatski zemaljski glazbeni zavod, 1912.

Izvješće glazbene škole Hrvatskoga zem. glazbenog zavoda u Zagrebu za školsku godinu 1912.-1913. Zagreb: Hrvatski zemaljski glazbeni zavod, 1913.

Izvještaj Konzervatorija Hrvatskoga zemaljskoga Glazbenoga zavoda u Zagrebu za školsku godinu 1916-1917. Zagreb: Hrvatski zemaljski glazbeni zavod, 1917.

Izvještaj Konzervatorija Hrvatskoga zemaljskoga glazbenoga zavoda u Zagrebu za školsku godinu 1919.-1920. Zagreb: Hrvatski zemaljski glazbeni zavod, 1920.

Kralik, Heinrich. Das Buch der Musikfreunde. Zürich, Leipzig, Wien: Gesellschaft der Musikfreunde, 1951.

Majer-Bobetko, Sanja. »Vjekoslav Klaić«. V Hrvatski biografski leksikon, http:// hbl.lzmk.hr/clanak.aspx?id=214. 
Moser, Vitězslav Roman. Tehničke vježbe za gusle, za porabu učenicima i učenicama Narodnoga zemaljskoga glasbenoga zavoda, 2 zvezka. Zagreb: Tiskara i litografija C. Albrechta, 1894.

Polášek, Žiga (Sigismund), Josip (Josef) Vedral. Slovenski mladini: Album 25 slovenskih pesmi za gosli s spremljevanjem klavirja. Ljubljana: Glasbena matica, 1913. http://www.dlib.si/?URN=URN:NBN:SI:DOC-AZVPBWHE.

Pravila Družtva prijateljah muzike u Zagrebu. Zagreb: Družtvo prijateljah muzike u Zagrebu, 1852.

Premrl, Stanko. »Stöckl, Anton«. Slovenska biografija. Ljubljana: Slovenska akademija znanosti in umetnosti, Znanstvenoraziskovalni center SAZU, 2013. https://www.slovenska-biografija.si/oseba/sbi614474/.

Razinger, Anton. Začetne pevske vaje. Ljubljana: Glasbena matica, 1885. http:// www.dlib.si/?URN=URN:NBN:SI:DOC-5VKPAW30.

Stöckl, Anton. Kratak opći nauk o glasbi za učenike glazbene škole Hrv. zemaljskoga glazbenoga zavoda. Zagreb: Hrvatski zemaljski glazbeni zavod, 1899.

Šaban, Ladislav. »Muzička škola Hrvatskog glazbenog zavoda u Zagrebu (18291920)«. V Razvoj muzičkog školstva u SR Hrvatskoj 1788-1968, katalog razstave, 27-39. Zagreb: s. n., 1968.

Šaban, Ladislav. 150 godina Hrvatskog glazbenog zavoda. Zagreb: Hrvatski glazbeni zavod, 1982.

Zöllner. Štirideset vaj v petju. Ljubljana: Glasbena matica, 1908. 